$1-2012$

\title{
The School Success Program: Improving Maltreated Children's Academic and School-related Outcomes
}

Christopher A. Mallett

Cleveland State University, c.a.mallett@csuohio.edu

Follow this and additional works at: https://engagedscholarship.csuohio.edu/clsowo_facpub

Part of the Educational Assessment, Evaluation, and Research Commons, Educational Methods

Commons, and the Social Work Commons

How does access to this work benefit you? Let us know!

Publisher's Statement

This is a pre-copyedited, author-produced PDF of an article accepted for publication in Children and Schools following peer review. The definitive publisher-authenticated version is available online at http://cs.oxfordjournals.org/content/34/1/13

\section{Recommended Citation}

Mallett, Christopher A., "The School Success Program: Improving Maltreated Children's Academic and School-related Outcomes" (2012). Social Work Faculty Publications. 12.

https://engagedscholarship.csuohio.edu/clsowo_facpub/12

This Article is brought to you for free and open access by the School of Social Work at EngagedScholarship@CSU. It has been accepted for inclusion in Social Work Faculty Publications by an authorized administrator of EngagedScholarship@CSU. For more information, please contact library.es@csuohio.edu. 


\title{
The School Success Program: Improving Maltreated Children's Academic and School-related Outcomes
}

\author{
Christopher A. Mallett
}

\begin{abstract}
Many victims of childhood maltreatment experience diffculties in school and with academic performance. This article reviews the evidence on the connection between childhood maltreatment and school performance and presents an evaluation of a unique program established by Children's Services in Lorain County, Ohio. Since 2001, the School Success Program, in collaboration with 18 Ohio public school districts, has provided individual tutoring and mentoring by certified teachers to 615 maltreated children and youths, working closely with the whole family in an in-home setting. Most children and youths in the program have progressed to their appropriate grade level while improving overall grade point averages from 1.74 to 2.56 in core academic subjects. Program participants have shown one-year improvements that are significant when compared with those of their nonmaltreated peers: Basic reading and comprehension skills improved 58 percent; math reasoning and comprehension skills improved 50 percent; basic writing skills improved 48 percent; and overall academic skills improved 51 percent. These improvements were seen across both gender and race, with almost equal gains made by minority and nonminority children and youths, but particularly by boys. Implications for school social work practice are set forth in light of these promising results.
\end{abstract}

KEY WORDS: children; maltreatment; mentor; school; tutor

A cademic success is vital for children and youths to transition without difficulty to adolescence and young adulthood (Buehler, Orme, Post, \& Patterson, 2000). This transition is markedly more difficult for many children who have been victims of maltreatment. Abuse and neglect may affect children's abilities to learn, decrease cognitive and language capacities (Smithgall, Gladden, Howard, Goerge, \& Courtney, 2004), increase risk for special education disabilities, decrease standardized testing outcomes (Egeland, 1997), and decrease overall academic performance (Leiter, 2007). It is important to develop interventions and programs targeted specifically to this population that has experienced abuse, neglect, or both to provide these children and youths the opportunity to achieve school-related success. These interventive efforts may have long-lasting and important future impacts (Veltman \& Browne, 2001).

This investigation provides descriptive and longitudinal findings for a program initiated in 2001 in one Ohio county's children's services agency that is trying to address and improve the academic and school-related outcomes for maltreated children and youths. Finding evidence of what may work to address this child welfare, school social work, and public education situation is important not only because academic difficulties are a common problem for maltreatment victims, but also because few programs have been designed specifically to target this problem (Tolan, Henry, Schoeny, \& Bass, 2007; Wilson, Gottfredson, \& Najaka, 2001).

\section{BACKGROUND}

\section{Child Maltreatment}

Child maltreatment includes neglect and physical, sexual, and psychological abuse. Child protective services agencies nationwide confirmed 903,000 children as maltreated in 2007 (approximately 1.2 percent of all children and youths in the United States), an increase of 10 percent since 1990. A majority of these confirmed cases were for neglect (63 percent), with fewer cases of physical abuse (17 percent), psychological abuse (11.5 percent), and sexual abuse (9.5 percent) (U.S. Department 
of Health and Human Services, 2009a). Maltreatment affects many of these children and youths in harmful ways, increasing risk for lower school achievement, juvenile delinquency, substance abuse, mental health problems, and other young adult difficulties (Hawkins et al., 2000; Tuell, 2002; U.S. Department of Health and Human Services, 2003; Wiggins, Fenichel, \& Mann, 2007).

\section{Impact of Maltreatment on School Performance}

There is strong evidence, though significant study methodology variance, that maltreated children and youths have poorer academic outcomes (Leiter, 2007). Most researchers have looked at maltreatment as a distinct variable, whereas fewer researchers have investigated the impact that a specific type of abuse or neglect had on school performance. Generalization of this research knowledge is possible because many of the recent studies used random samples, many designs were prospective (though earlier designs were primarily crosssectional, identifying maltreatment and educational outcomes retrospectively), and the designs controlled for many other possible explanatory impacts on school performance. Known influences on school performance that were controlled for included poverty, family characteristics, social and peer influences, and neighborhoods. Use of comparison groups has also been consistent; studies compared a maltreated cohort with a nonmaltreated but demographically similar cohort (Boden, Horwood, \& Fergusson, 2007; Staudt, 2001). A review of the studied outcomes found a focus on intellectual development (75 percent of studies), language development ( 86 percent of studies), and academic achievement (91 percent of studies), with 74 percent of studies using comparison group designs (Veltman \& Browne, 2001). Recent studies have continued these methodology trends (Leiter, 2007).

Primary School. Maltreated children are more likely to have poorer grades and be held back a grade level (Brown, 2000; Eckenrode, Laird, \& Doris, 1993; Kelley, Thomberry, \& Smith, 1997; Shonk \& Cicchetti, 2001), particularly in kindergarten and first grade (Rowe \& Eckenrode, 1999). This result was also found for children in the school year after they entered out-of-home care (Smithgall et al., 2004). It is not clear how child welfare agency and family involvement affect these school delays and being held back, though frequent moves and changes can create or exacerbate educational difficulties (Ayassee, 1995; National Youth in Care Network, 2001). Many of these maltreated children also experienced poverty, an identified influence on poor academic outcomes. However, even when poverty was controlled for, maltreatment was found to have a harmful impact on scholastic performance (Barnett, Vondra, \& Shonk, 1996).

Cognitive and language delays, apparent at the school enrollment age, are greater for maltreated children than for nonmaltreated children from lower socioeconomic backgrounds and much greater than for nonmaltreated children from higher socioeconomic backgrounds (Wiggins et al., 2007). On average, maltreated students enter school one-half year behind on academic performance (Smithgall et al., 2004) and have poorer academic performance and adaptive functioning at ages six and eight than nonmaltreated children (Kurtz, Gaudin, Wodarski, \& Howing, 1993; Zolotor et al., 1999). These students also have higher absenteeism rates than nonmaltreated children (Lansford et al., 2002; Leiter, 2007; Leiter \& Johnsen, 1997).

It is less clear if specific types of abuse or neglect have differential impacts. Physical abuse has been found both to negatively affect academic achievement, grades specifically (Hoffman-Plotkin \& Twentyman, 1984; Leiter \& Johnsen, 1994), and to have no impact on academic achievement (Eckenrode et al., 1993; Kurtz et al., 1993). The impact of sexual abuse on academic outcomes is unclear to date, though reviews are limited, with contradictory findings on the effect of abuse on intellectual abilities (Veltman \& Browne, 2001). However, the impact of neglect on children's academic outcomes has consistently been found to be harmful, particularly to grades and overall academic skills (Allen \& Oliver, 1982; Eckenrode et al., 1993).

It should be noted, however, that many children experience more than one type and one occurrence of maltreatment, and the cumulative and interactive effects of these multiple experiences complicate research findings (Margolin \& Gordis, 2000; U.S. Department of Health and Human Services, 2009a). Some researchers have identified that the severity of abuse has a negative impact on 
verbal abilities and verbal IQ (Perez \& Widom, 1994). The more serious or pervasive the maltreatment, the greater the risk for the child's decline in school performance, including absenteeism and grades. Maltreatment at an earlier age may lead to behavior problems and increased placement into special education programs (Leiter \& Johnsen, 1997).

Compared with nonmaltreated children, maltreated children are less inclined to engage in independent activities, require more external motivations, and show less academic engagement (Koenig, Cicchetti, \& Rogosch, 2000; Shonk \& Cicchetti, 2001; Toth \& Cichetti, 1996). They also show less effective work habits and discipline and receive lower math and English grades during elementary school (Rowe \& Eckenrode, 1999). However, improving academic engagement and increased work with the maltreated children improves school outcomes (Gray, Nielsen, Wood, Andresen, \& Dolce, 2000; Shonk \& Cicchetti, 2001).

Maltreated children, and particularly children in foster care, are more likely than their nonmaltreated peers to be diagnosed with a special education disability during earlier school yearsupward of 35 percent are diagnosed with such a disability (Children's Law Center, 2003; Frothingham et al., 2000; Goerge, VanVoorhis, Grant, Casey, \& Robinson, 1992; Leiter \& Johnsen, 1997; Scarborough \& McCrae, 2010). Children in foster care also have poorer academic achievement than their peers (Burley \& Halpern, 2001; Fanshel \& Shin, 1978). In one review, these children were 96 percent below their grade level in reading comprehension and 95 percent below in mathematics (Hyames \& de Hames, 2000). Others have also found this impact to be strong, with children in foster care half as likely to perform at grade level (Conger \& Rebeck, 2001) and upward of 50 percent held back one grade (Children's Law Center, 2003). Children in out-of-home care do not seem to fall further behind in reading achievement while in care, but the achievement gap remains (Smithgall et al., 2004).

Secondary School. Maltreatment has been found to affect older students' academic and related outcomes (Courtney, Roderick, Smithgall, Gladden, \& Nagaoka, 2004; Wodarski, Kurtz, Gaudin, \& Howing, 1990). More intense or long- lasting maltreatment was found to be associated with low grade point averages and problems completing homework assignments, though the impact was moderated by cognitive deficits (Slade \& Wissow, 2007). Courtney, Terao, and Bost (2004) reported that older maltreated adolescents were three or four grade levels behind in reading abilities and that, compared with their nonmaltreated peers, significantly more had repeated at least one grade. In one survey of children in out-of-home care, middle-school youths were three times more likely to be identified as in need of special education services, with almost all youths in this study with leaming disabilities scoring below national reading norms (Smithgall et al., 2004).

Many maltreated youths also scored significantly lower on standardized and required proficiency examinations (Egeland, 1997): In Chicago, onefourth of maltreated children scored in the bottom quartile on the Iowa Test of Basic Skills (Smithgall et al., 2004); in Ohio, only one-fourth of ninthgrade students in foster care passed the mathematics and science tests, and only one-half passed the reading proficiency tests (Coleman, 2004); and in Washington, youths in care scored on average 15 to 20 points lower on the statewide achievement tests than their nonmaltreated peers (Burley \& Halpern, 2001). These poor outcomes are also found when other countries' maltreated youth populations are studied (Colton \& Heath, 1994; Jones, Trudinger, \& Crawford, 2004).

Some researchers have found that maltreated (measured as one variable) students have significantly lower high school graduation rates than nonmaltreated students (Blome, 1994; Boden et al., 2007; Buehler et al., 2000; McGloin \& Widom, 2001; Tate, 2000; Thornberry, Ireland, \& Smith, 2001). Children and youths in foster care are particularly at risk, with 46 percent not completing high school (Children's Law Center, 2003). When further investigated, neglect was found to have a strong negative impact on academic achievement and high school graduation rates, physical abuse a slight impact, and sexual abuse no impact (Eckenrode et al., 1993; Fang \& Tarui, 2009; Wodarski et al., 1990). However, physical and sexual abuse have also been found not to be associated with later high school graduation attainment, after controlling for socioeconomic status (Boden et al., 2007). 


\section{Intervention Strategies}

In-Class Programming. It is important to address these school performance and academic deficiencies for all children and youths who have experienced maltreatment. Underachievement in the classroom and placement in remedial classrooms are associated with school dropout, deviant peer friendships, and delinquency (Mears \& Aron, 2003; Patterson, DeBaryshe, \& Ramsey, 1989). These potentially harmful outcomes for maltreated children and youths are not inevitable; some youths succeed with little to no assistance (Hamilton \& Browne, 1998). However, many maltreated children may benefit from efforts to improve their academic performance (Veltman \& Browne, 2001).

Strong evidence shows that school-based teaching and programs help students who are behind in academic performance or at risk of failing a grade. One school-based area is the everyday classroom setting and interactions between teachers and children, with knowledge of how to be effective at ameliorating these academic risks (National Institute of Child Health and Human Development Early Child Care Research Network, 2003; Pianta, LaParo, Payne, Cox, \& Bradley, 2002). A second school-based area is interventions designed to help or address varying risk factors for these students (Greenberg et al., 2003; Wilson et al., 2001). Virtually no programs or school-based interventions tailored to academic problems of maltreated students exist, however.

Mentoring and Tutoring Programs. Significant evidence shows that both mentoring and tutoring as stand-alone interventions are effective for many at-risk children and youths. Mentoring, particularly programs based on the Big Brothers/Big Sisters model, has been shown to be effective on a wide range of child and youth difficulties. Program participants (ages six to 18) show significant improvements compared with noninvolved at-risk children and youths in academic behavior, attitudes, and performance and in improved relationships with parents and peers (McGill, Mihalic, \& Grotpeter, 1998; Novotney, Mertinko, Lange, \& Baker, 2000). More specifically, in a review of 39 mentoring programs (Tolan et al., 2007), although most were found to effectively produce positive outcomes for the children and youths, mentors with a professional background were more effective than mentors without a professional background. Although it is known that the relationship between a mentor and a child is most important, the specific processes or program structures beyond this still need to be identified if we are to know which programs are more effective and why (Tolan et al., 2007).

Tutoring models and programs range from high to low in structure and from using volunteer to paraprofessional to professional tutors (Fashola, 2001). A review of 28 adult, nonprofessional volunteer tutor programs (all studies used a comparison group with a one-month tutoring duration minimum) for school-age children (kindergarten through eighth grade) found positive impacts on reading and language outcomes, specifically overall reading, oral fluency, letter and word identification, and writing. No significant differences were found between volunteer tutor type, grade level, and program focus (Ritter, Denny, Albin, Barnett, \& Blankenship, 2007). Reviews of certified teachers (professional) as stand-alone tutoring programs are limited in the literature. An early review of five tutoring programs, including both professional and nonprofessional tutors, found the reading improvements for children to be significant, very much justifing the programs costs (Wasik \& Slavin, 1990). A meta-analysis of 29 tutoring programs that included both adult nonprofessional and adult trained-professional volunteers also found that these programs were effective at improving reading abilities for elementary school children (Elbaum, Vaughn, Hughes, \& Moody, 2000). More recently, the Reading Recovery tutoring model was found to be highly effective in improving participants' alphabetic skills and general reading achievement outcomes in five separate studies (two conducted in Ohio). This model uses certified teachers, takes place during the school day, and is designed for the lowest achieving (lowest 20 percent) first-grade students, with tutoring discontinued when a student consistently reads at the grade level average-normally between 12 and 20 weeks (U. S. Department of Education, 2007a).

\section{Summary of the Literature}

In summary, maltreated children and youths have poorer academic outcomes than do their nonmaltreated peers. Some of these outcomes include poorer grades, retainment for grade repetition, cognitive and language delays, poor work habits, 
increased prevalence of special education disabilities, and lower standardized and proficiency test scoring. In Lorain County, Ohio, these poorer outcomes for maltreated children and youths were identified by the children's services agency. To address these deficiencies and concerns, Lorain County Children's Services initiated and has continued the School Success Program. To evaluate whether this program is having an impact, this initial pilot study was completed and reported. This evaluation asked this question: Does the School Success Program have a positive impact on the academic and school-related outcomes of these maltreated children and youths?

\section{LORAIN COUNTY, OHIO, CHILDREN'S SERVICES' SCHOOL SUCCESS PROGRAM}

\section{Program Design}

The major focus of the School Success Program is to provide a consistent adult, who is also a certified teacher, to tutor each child, individually and in his or her home. The match between certified tutor/mentor and child is based on the educational needs of the child, the tutor's abilities, and the personality styles of both. Often practice wisdom and the program supervisors' long history and work with the families are instructive as to the tutor/mentor type that may work best with a child or youth. (The program is run by the county's children's service agency, so in this smaller sized jurisdiction, there is often a wellknown family history.) Also, a very large majority of the tutors/mentors have been with the program for numerous years, allowing the program to know and understand their styles, strengths, and weaknesses. Matches are monitored by supervisors to ensure an ongoing best fit. This best fit model is achieved through the assessment of the work, relationship building, and outcomes/ progress of the tutors/mentors, children, and the children's families. The tutor/mentor works with the child, family, Children's Services School Success worker, and classroom teachers in a team environment. Children and tutors/mentors meet between one and four hours per week (or more if necessary), depending on the child's needs, and focus their individualized educational support plans on Ohio benchmarks (the standard in all Ohio public schools), local public school system skills sets, and other issues that may be impeding success. Individual student program progress is assessed throughout by the full team via weekly progress reports and monthly review documents and formally every five months for children and youths with ongoing involvement with Children's Services. (A program manual is available from Christopher A. Mallet.)

This combination of tutoring and mentoring by a certified teacher in an in-home setting was designed to address these maltreated children's academic deficits. In addition, as recommended by the tutor/mentor, a personal computer with appropriate and necessary educational software is also provided to the families on a library loan basis. The program's goals for each child are to instill the ability to understand school work and experience school success; to teach study habits and routines to follow in the home; to provide a consistent, interested person to the child and family; and to advocate when additional, special services (particularly special education) may be necessary or available through the public school system.

\section{METHOD}

\section{Design}

This longitudinal design evaluation was of a program using an open and rolling enrollment process, based on the needs of the maltreated children (and families) (Yegidis \& Weinbach, 2009). Different measures have been used over time and modified to improve the evaluation. Program completion and discharge criteria up through 2008 were based on individualized child (and family) progress and goal attainment. However, in 2008 , because of fiscal constraints, discharge criteria for children and youths were set at the 24-month mark of program participation, regardless of individualized goal attainment.

\section{Program Population}

The School Success Program began in the 200102 academic year with 15 children from foster care home supervision and expanded to approximately 60 children from both foster care and relative supervision settings at the end of the 2003-04 academic year. The Children's Services Agency set up the program in conjunction with the Elyria, Ohio, school district to help the academic progress for these supervised children. In 
the 2004-05 academic year, due to initial identified success of progression to an age-appropriate academic level by each child, the program was expanded to all grade levels (kindergarten through 12th grade) and school systems in Lorain County and in surrounding counties when a child was placed there and to agency-supervised children in a variety of home settings (adoptive, relative, custody, and foster). In the 2005-06 academic year, the program was significantly expanded and offered to children and youths who were in their own homes, as long as their families were, or had been, involved with the Children's Services Agency. Higher enrollments occurred in 2007 and 2008 , but due to budget losses, the program enrollment decreased to between 150 and 175 children during the 2008-09 academic year. In total, 615 children and youths were enrolled in the School Success Program from 2001 to 2009, with an average program participation length of 21 months. These children and youths were in all grades (kindergarten through 12th grade), although a majority of them were in primary school (kindergarten through sixth grade: 62 percent, $n=381$; seventh grade through 12th grade: 38 percent, $n=234$ ). Of participants, 58 percent $(n=357)$ were Caucasian, 31 percent $(n=191)$ African American, and 11 percent $(n=67)$ Hispanic; 55 percent $(n=338)$ were male, and 45 percent were $(n=277)$ female; and 54 percent $(n=332)$ were placed by the Children's Services Agency outside of their home.

\section{Pilot Studies-Measures}

The initial program pilot studies conducted in 2002 and 2003 used parent, teacher, and student surveys and interview feedback along with school grade point average tracking and found initial improvements for the participants. Early pilot evaluations of the program and its expansion from 2003 to 2005 continued to use student grade point averages, student grade placement levels, and stakeholder surveys.

\section{Full Study-Measures and Data Analysis}

This evaluation of the program included the following student measures: Woodcock Johnson III Assessment scores (2006 through 2009), grade point averages (2001 through 2007), and special education disability identification and services (2001 through 2009).

The standardized Woodcock Johnson Assessment measures general intellectual ability, specific cognitive abilities, scholastic aptitude, oral language, and overall academic achievement and reports these results as basic reading, reading comprehension, math calculations, math reasoning, basic writing, and overall academic skills scores (McGrew, Dailey, \& Schrank, 2007). These measures were completed once per academic year for participants beginning in the 2006-07 academic year $(\mathrm{T} 1=$ first time measurement). The basic reading cluster score is a combination of letterword identification and word attach skills and is an aggregate measure of sight vocabulary, phonics, and structural analysis. The reading comprehension cluster score is a combination of passage comprehension and reading vocabulary skill. The math calculation cluster score is a measure of computational skills and automaticity with basic math facts and provides a measure of basic mathematical skills. The math reasoning cluster score is a combination of applied problems and quantitative concepts and provides a measure of mathematical knowledge and reasoning. The basic writing skills cluster score is a combination of spelling and editing and provides a measure of ability to spell single-word responses and identify errors in spelling, punctuation, capitalization, and word usage. The academic skills cluster score is a measure of the other skills combined into an overall score (McGrew et al., 2007). These scores are measured as grade equivalency. T1 score measurements compared with later (time 2 [T2, 12 months later] and time 3 [T3, 24 months later]) score measurements were assessed for statistically significant differences using a series of paired samples $t$ tests $(p<.05)$.

Grade point averages for the students were calculated using only the core academic subject areas: writing, math, and reading. Use of these subject grades (converted to a 4.0 grade point scale) matches the national measurement criteria (U.S. Department of Education, 2007b). These student grade reports for specific academic years were aggregated and averaged to determine the program populations' overall scores.

Special education disabilities were determined by the Individuals with Disabilities Education Act (2004) and had numerous diagnostic and 
academic categories. If the program was responsible for initial identification and subsequent access to special education services through the school system, this was then measured and counted toward one of the program's goals.

\section{RESULTS}

\section{Woodcock Johnson Assessment}

From 2006 to 2009, 206 program participants were measured with the Woodcock Johnson Assessment, with 109 of these same children and youths measured a second time and 30 a third time. Although measurements for later times were not fully available for all participants, those provided were tracked longitudinally on the same children and youths. The decrease in number of follow-up measurements was due to program limitations and funding decreases.

It is expected in school classrooms that each child will progress one academic year per subject for each grade level. In other words, a child in the fifth grade should be reading, writing, and doing math at the fifth grade level. As shown in Figure 1, the grade level change for the program participants from the first measurement (T1) to the second measurement (T2) was one-half year (0.50); however, their math comprehension improved more than one full grade level equivalent (1.01). This means that, compared with the expected norm for all students at these grade levels, the program participants improved more than twice as quickly in math comprehension skills during this time period (McGrew et al., 2007).

Before enrollment in the program, children and youths were on average over one academic year behind in their overall abilities and even further behind in reading comprehension. In one year in the program, these students $(n=109)$ improved their academic skill levels twice as quickly as the national norm, per the Woodcock Johnson Assessment (McGrew et al., 2007). At the end of two years, students $(n=30)$ still in the program had caught up to their peer norms in basic reading, math reasoning, and overall academic skills. The students measured a second and third time were very similar to the overall program population regards gender, race, primary/secondary school, and agency placement.

Examination of these improvements in academic abilities for gender, race, and location (whether living with a relative, in their own home, or placed by the Children's Services Agency), showed particularly strong gains made by boys (minority and Caucasian) and all children in an agency-directed placement. Boys exhibited gains between 66 percent and 72 percent in every core subject measured during the first year, and the significant gains during the second year were more

\section{Figure 1: Woodcock Johnson Assessment Scores for School Success Program Participants}

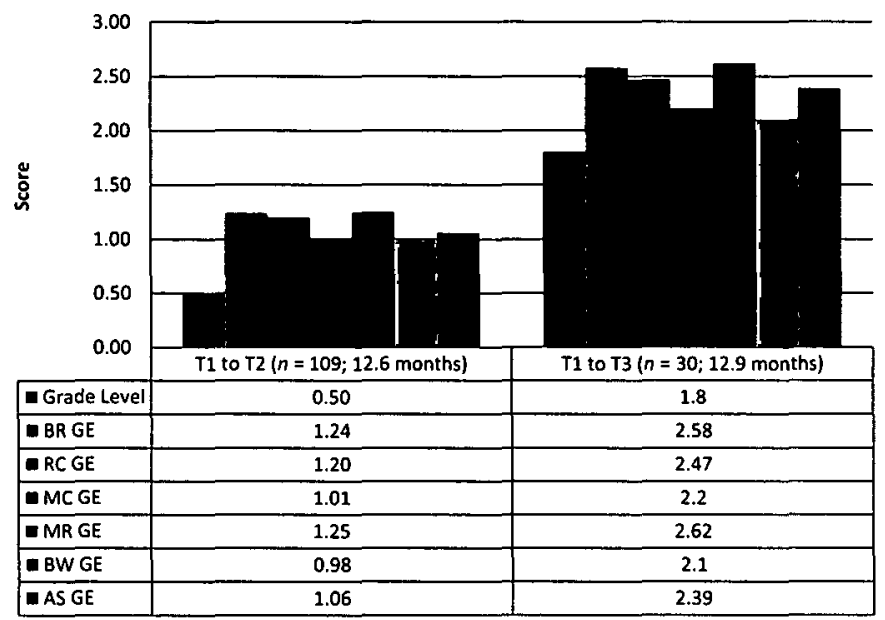

Notes: All score changes are significant at $p<.05 . T 1=$ time $1 ; \mathrm{T}=$ time $2 ; \mathrm{T} 3=$ time 3; BR = basic reading; $\mathrm{GE}=$ grade equivalency; $R C=$ reading comprehension; $\mathrm{MC}=$ math calculations; $M R=$ math reasoning; $B W=$ basic writing; $A S=$ overall academic skills. 
attributable to the boys' improvements than the girls' (see Table 1 and Figure 2). Although improvements continued between the second and third years, the rate of improvement declined, more so for the girls, except in basic writing skills. There was little disparity between minority (African American and Hispanic) and Caucasian children's improvements except in reading comprehension and basic writing skills, in which minorities advanced but at a slower pace than Caucasians (see Table 1 and Figure 3). The most significant academic progress was achieved by those children and youths in placement (adopted, in-custody, and foster care), in whom over 91 percent improvement across all academic areas was found during the first year of program participation (see Table 1 and Figure 4).

On the basis of the standardized Woodcock Johnson Assessment, these children and youths have made significant progress. A second, albeit nondirect, assessment is to see how these results compare with those of their public school student peers-in other words, their nonmaltreated classmates. The Ohio Department of Education tracks reading, writing, and math achievement for all students across public school districts and measures this progress with grade-level proficiency examinations. The two school districts important to review are the Lorain and Elyria City Public School Districts, because 64.3 percent of the School Success Programs' participants were referred from these two districts.

In the Lorain City Public Schools, third, sixth, and 10th graders' proficiency exam passage rates decreased by 6 percent per year from 2006 to 2009; fourth graders were an exception, improving their passage rates by 8 percent. In the Elyria City Public Schools, the exam passage rate also decreased during this time period, although by 2 percent on average per year. More poignantly, in the Lorain schools, boys passed the proficiency exam across all grades (third through 12th) at lower rates than girls (with two-thirds of the passage rate categories having more girls pass than boys), and minority youths (African American and Hispanic) had lower passage rates for almost every grade and tested category. In Elyria schools, there were no gender disparities in proficiency test passage rates across the grades; however, minority youths across nine different grades passed these test sections at lower rates than nonminority

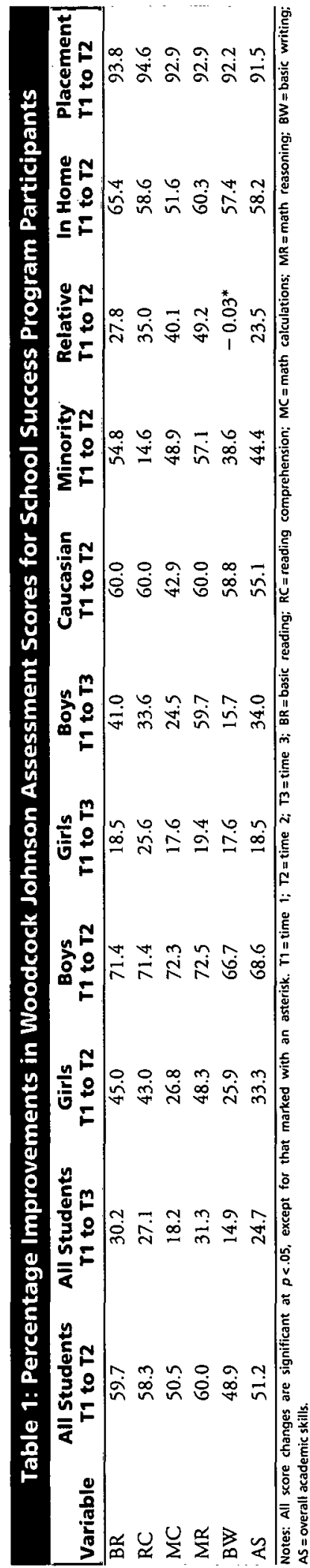


Figure 2: Woodcock Johnson Assessment Scores for School Success Program Participants by Gender

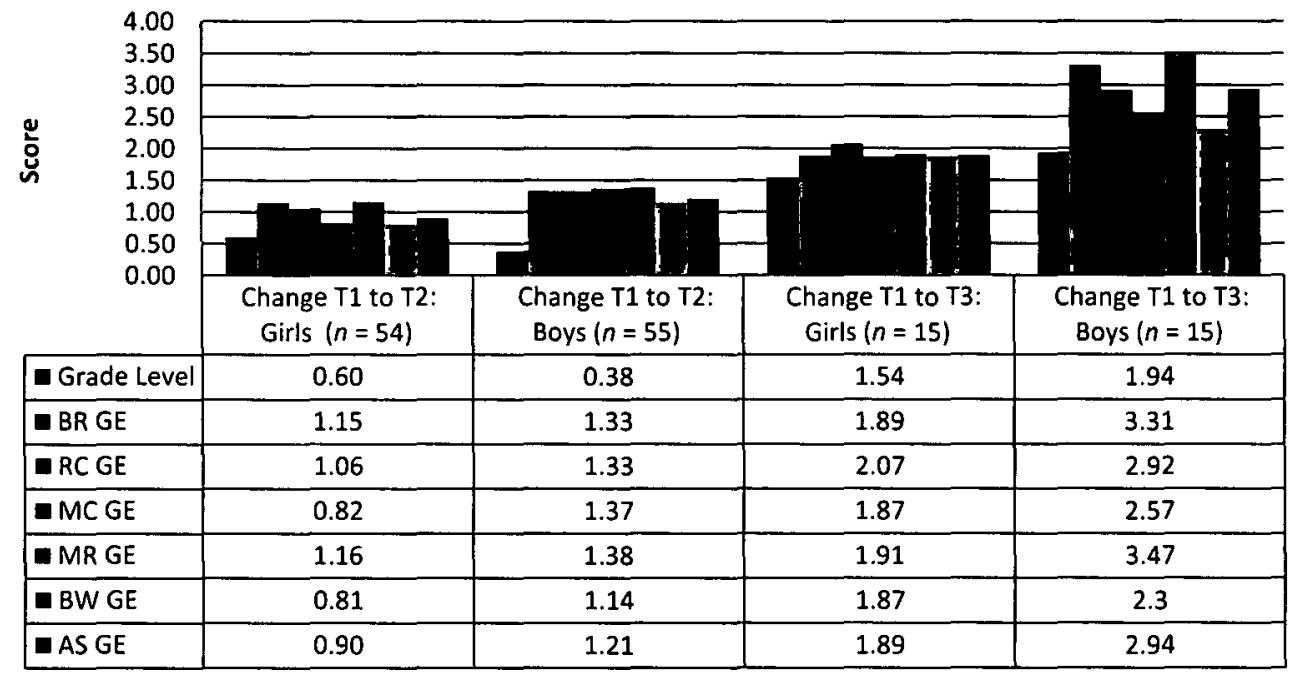

\section{Figure 3: Woodcock Johnson Assessment Scores for School Success Program Participants by Race}

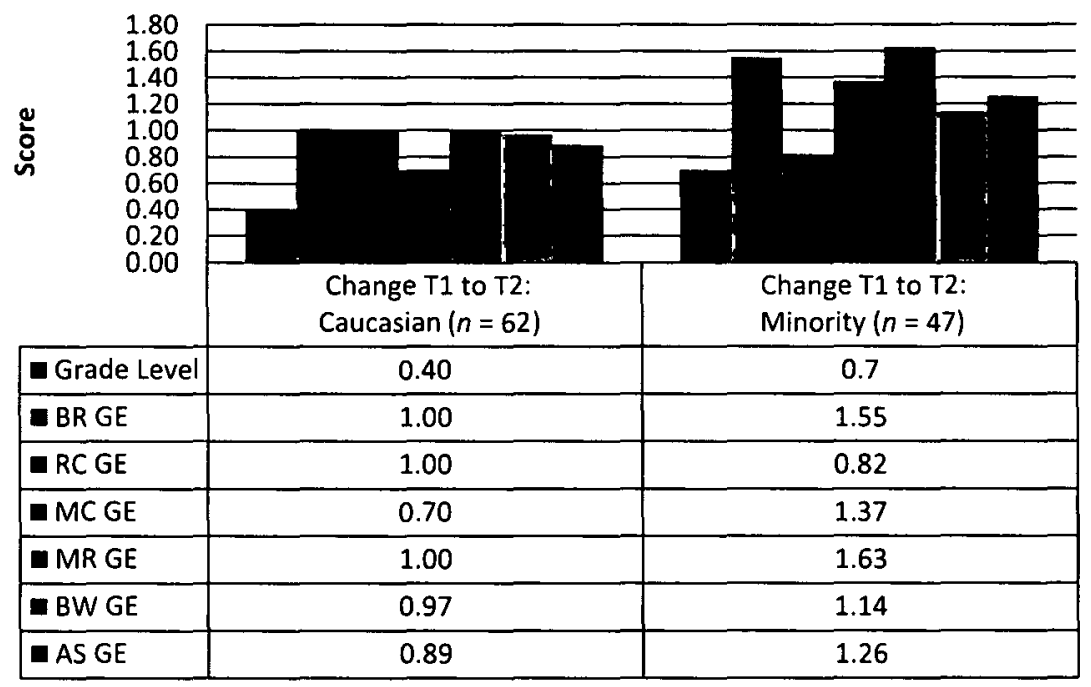

Notes: All score changes are significant at $p<.05 . \mathrm{T} 1=$ time $1 ; \overline{\mathrm{T}}=$ time $2 ; \mathrm{T} 3=$ time 3; $\mathrm{BR}=$ basic reading; $\mathrm{GE}=$ grade equivalency; $\mathrm{RC}=$ reading comprehension; $\mathrm{MC}=$ math calculations; $M R=$ math reasoning; $B W=$ basic writing; $A S=$ overall academic skills.

youths, with only four exceptions (Ohio Department of Education, 2009). The children and youths' overall academic success, as measured by state proficiency tests in these two public school districts, decreased. Although not a direct comparison-not possible because of incomplete 
Figure 4: Woodcock Johnson Assessment Scores for School Success Program Participants by Location

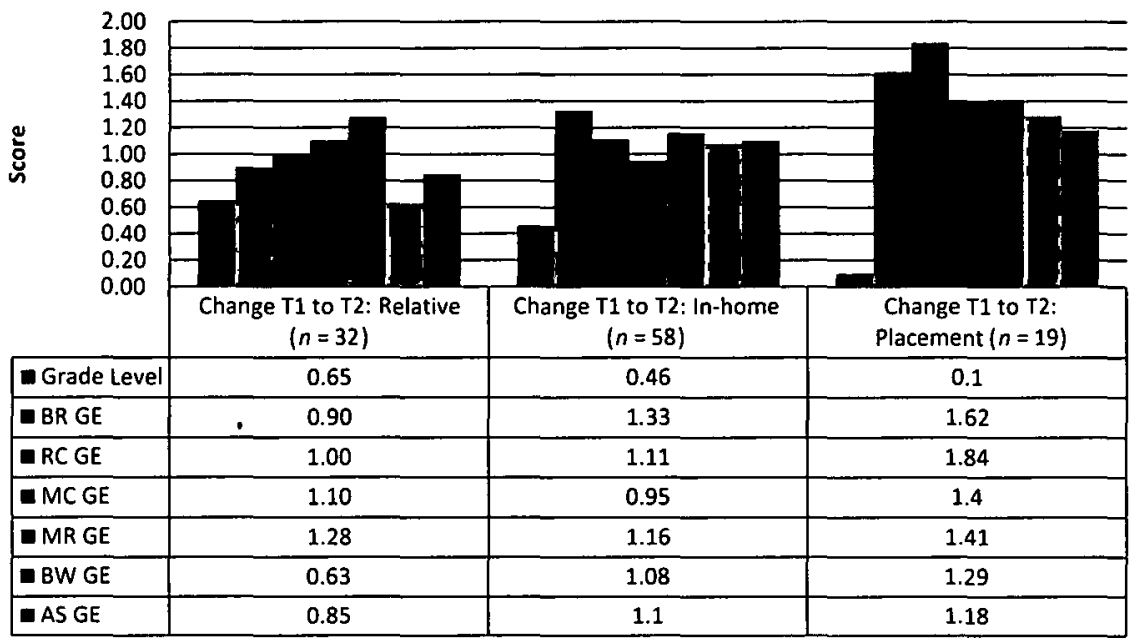

Notes: All score changes are significant at $p<.05$ except BW T1 to $T 2$. $T 1=$ time $1 ; T 2=$ time $2 ; T 3=$ time $3 ; \mathrm{BR}=$ basic reading; $\mathrm{GE}=$ grade equivalency; $\mathrm{RC}=$ reading comprehension; $M C=$ math calculations; $M R=$ math reasoning; $B W=$ basic writing; $A S=$ overall academic skills.

\section{Figure 5: Grade Point Averages of School Success Program Participants}

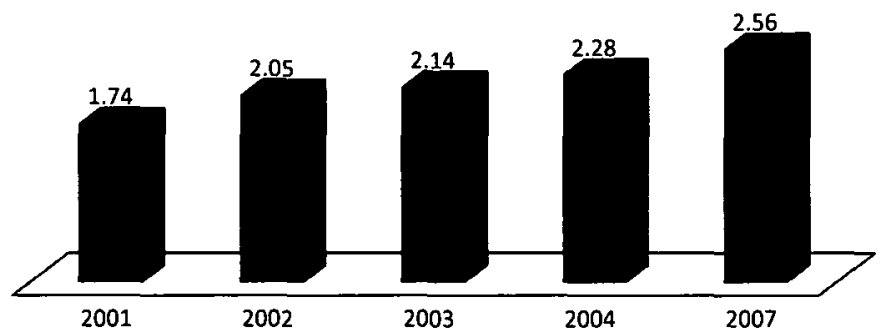

program participants' proficiency exam data-the children and youths in the program made significant progress across these same tested areas over the last three years studied, as measured with the Woodcock Johnson Assessment. Most interesting, it looks like boys in the program made gains at a quicker pace than girls, and both minority and nonminority children and youths made gains at almost an identical pace, something that did not happen for their nonmaltreated peers in these public school districts.

\section{Grade Point Averages}

Program participants' grade point averages in core subjects (writing, math, and reading) improved nearly one full point, equal to more than one full letter grade, over seven years of programming (see Figure 5). The most recent grade point calculations (2.56) placed these students nearly on par with the national average for public school students in these same core academic subjects (2.73) (U.S. Department of Education, 2007b). 


\section{Special Education Disabilities}

As a result of the program's advocacy efforts, over 19 percent of participants were identified as having a special education disability. This percentage of participants identified as in need of disability services is much higher than the public school norm of between 4 percent and 9 percent of students (Mears \& Aron, 2003).

\section{DISCUSSION}

In answer to the research question of whether the School Success Program has a positive impact on the academic and school-related outcomes of maltreated children and youths, the results look promising. These program results are potentially important in light of the uniqueness of the intervention-using certified professional teachers as tutors, and mentors who worked in the child's home and were available as needed to improve academic habits, focus, and outcomes. Because of the across-the-board difficulties many maltreated children and youths experience with their school work and performance, efforts to bridge and improve these outcomes are important. The improvements that were found here are arguably remarkable in light of the many other challenges these children and families were dealing with, including involvement with the Children's Services Agency because of identified abuse or neglect issues. These children were experiencing difficulties most children never face: Almost half (54 percent) were living in out-of-home care and going through other related transitions, and almost 19 percent were identified with special education disabilities.

\section{Evaluation Limitations}

Although the program looks to be a strong possible explanation for these participants' improved academic abilities, evaluation limitations narrow this claim. The evaluation design followed only the program participants and did not include a comparison group of similarly maltreated children who did not receive the intervention. This limitation is important to note and to include in future program evaluation planning to improve the evaluation's internal validity. It was also not possible to compare the potential differing levels of the intervention (whereby one participant may have received the service for two hours per week, compared with four hours per week for a different participant and over different lengths of time). This dose comparison would also be important to incorporate in future evaluations to further explicate the intervention impact. In addition, because the evaluation plan evolved along with the program expansion, there are data limitations. The Woodcock Johnson Assessment scores were not available for all participants, and long-term measures were not available for all participants because of service termination. Last, it is recommended that program participants be measured and followed after termination to see if the program effects and academic gains hold over time.

\section{Implications for Practice}

Although we recognize the need for more rigorous evaluation, the potential impact of the School Success Program, or similar interventions, could be significant because of the population being served. Abused and neglected children who are under children's services' supervision are at high risk for many related and difficult problems that school social workers, school system personnel, substance abuse agencies, and juvenile (and criminal) courts may have to address in future years with these youths and families. It has been clearly established across many professional fields that early identification and prevention, one thing that this program clearly intends to provide, minimizes more difficult problems later and is extremely cost-effective (Benda \& Tollet, 1999; Holman \& Ziedenberg, 2006; Mears \& Aron, 2003).

This makes some of the present findings particularly intriguing. Maltreated children and youths who were in need of home removal and placement by the Children's Services Agency made the most significant progress in their first year of program enrollment. Also, minority children and youths (African American and Hispanic) made equal improvements, something not often found when working with and researching at-risk populations.

Wanting children and youths to perform at their academic school grade levels is common sense-something parents, teachers, and school personnel would be more than satisfied with most of the time. The School Success Program simply sets as its outcome goal that these norm school achievements - grades; reading, writing, and math abilities; and if needed, disability access-be met for children who have been victims of 
maltreatment. Recently, these efforts have been recognized by the Administration on Family and Children of the U.S. Department of Health and Human Services, which named the School Success Program a 2009 Promising Program (U.S. Department of Health and Human Services, 2009b).

\section{REFERENCES}

Allen, R. E., \& Oliver, J. M. (1982). The effects of child maltreatment on language development. Child Abuse E Neglect, 6, 299-305.

Ayassee, R. H. (1995). Addressing the needs of foster children: The foster youth services program. Social Work in Education, 17, 207-216.

Barnett, D., Vondra, J. I., \& Shonk, S. M. (1996). Self-perceptions, motivation, and school functioning of low-income maltreated and comparison children. Child Abuse \& Neglect, 20, 397-410.

Benda, B. B., \& Tollet, C. L. (1999). A study of recidivism of serious and persistent offenders among adolescents, Joumal of Criminal Justice, 27, 111-126.

Blome, W. W. (1994). A comparative study of high school and post-high school experiences of foster care and non-foster care youths: A secondary analysis of a national longitudinal study (Unpublished doctoral dissertation). Catholic University, Washington, DC.

Boden, J. M., Horwood, L. J., \& Fergusson, D. M. (2007). Exposure to childhood sexual and physical abuse and subsequent educational achievement outcomes. Child Abuse \& Neglect, 10, 1101-1114.

Brown, B. S. (2000). Meeting the educational needs of children in foster care, kinship care, and children uith disabilities. Cincinnati: Beech Acres.

Buehler, C., Orme, J. G., Post, J., \& Patterson, D. A. (2000). The long-term correlates of family foster care. Children and Youth Services Review, 22, 595-625.

Burley, M., \& Halpern, M. (2001). Educational attainment of foster youths: Achievement and graduation outcomes for children in state care. (Document No. 01-11-3901). Olympia: Washington State Institute for Public Policy.

Children's Law Center. (2003). Los Angeles education summit on needs and challenges facing foster youth: "Indentifying obstacles and forging solutions." Retrieved from http:// www.abanet.org/child/rclji/education/ed_ summitrec.pdf

Coleman, M. S. (2004). Children left behind: The educational status and needs of youth living in foster care in Ohio. Retrieved from http://inpathways.net/ childrenleftbehind.pdf

Colton, M., \& Heath, A. (1994). Attainment and behavior of children in care and at home. Oxford Review of Education, 20, 317-327.

Conger, D., \& Rebeck, A. (2001). How children's foster care experiences affect their education. New York: Vera Institute for Justice.

Courtney, M. E., Roderick, M., Smithgall, C., Gladden, R. M., \& Nagaoka, J. (2004). The educational status of foster children. Chicago: Chapin Hall Center for Children. Retrieved from http://www.chapinhall. $\mathrm{org} / \mathrm{research} / \mathrm{brief} /$ educational-status-foster-children

Courtney, M. E., Terao, S., \& Bost, N. (2004). Midurest evaluation of the adult functioning of former foster youth: Conditions of youth preparing to leave state care. Chicago: Chapin Hall Center for Children.

Eckenrode, J., Laird, M., \& Doris, J. (1993). School performance and disciplinary problems among abused and neglected children. Developmental Psychology, 29, 53-62.

Egeland, B. (1997). Mediators of the effects of child maltreatment on developmental adaptation in adolescence. In D. Cicchetti, \& S. L. Toth (Eds.), Rochester symposium on developmental psychopathology, volume 8, developmental perspectives on trauma: Theory, research, and intervention ( $\mathrm{pp}$. 403-434). Rochester, NY:

University of Rochester Press.

Elbaum, B., Vaughn, S., Hughes, M. T., \& Moody, S. W. (2000). How effecrive are one-to-one tutoring programs in reading for elementary students at risk for reading failure? A meta-analysis of the intervention research. Joumal of Educational Psycholog, 92 , 605-619.

Fang, X., \& Tarui, N. (2009, April 19). Child maltreatment, family characteristics, and educational attainment: Evidence from AddHealth data. Unpublished manuscript.

Fanshel, D., \& Shin, E.B. (1978). Children in foster care: $A$ longitudinal investigation. New York: Columbia University Press.

Fashola, O. S. (2001). Building effective afterschool progrants. Thousand Oaks, CA: Corwin Press.

Frothingham, T. E., Hobbs, C. J., Wynne, J. M. Yee, L., Goyal, A., \& Wadsworth, D. J. (2000). Follow up study eight years after diagnosis of sexual abuse. Archives of the Disabled Child, 83, 132-134.

Goerge, R. M., VanVoorhis, J., Grant, S., Casey, K., \& Robinson, M. (1992). Special education experiences of foster children: An empirical study. Child Welfare, $71,419-437$

Gray, J., Nielsen, D., Wood, L., Andresen, M., \& Dolce, K. (2000). Academic progress of children who attended a preschool for abused children: A follow-up of the keepsafe project. Child Abuse \& Neglect, 24, 25-32.

Greenberg, M. T., Weissberg, R. P., O'Brien, M. U., Zins, J. E., Fredericks, L., Resnik, H., et al. (2003). Enhancing school-based prevention and youth development through coordinated social, emotional, and academic learning. American Psychologist, 58, 466-474.

Hamilton, C. E., \& Browne, K. D. (1998). The repeat victimization of children: Should the concept be revised? Aggression and Violent Behavior, 3, 47-60.

Hawkins, J., Herrenkohl, T., Farrington, D., Brewer, D., Catalano, R. F., Harachi, T., \& Cothern, L. (2000). Predictors of youth violence. Retrieved from https:// www.ncjrs.gov/pdffiles1/ojjdp/179065.pdf

Hoffman-Plotkin, D., \& Twentyman, C. T. (1984). A multimodal assessment of behavional and cognitive deficits in abused and neglected preschoolers. Child Development, 55, 794-802.

Holman, B., \& Ziedenberg, J. (2006). The dangers of detention: The impact of incarcerating youth in detention and other secure congregate facilities. Baltimore: Annie E. Casey Foundation.

Hyames, S., \& de Hames, M. V. (2000). Educational experiences and achievement of children and youth in the care of the department receiving services from Chicago public schools. Urbana-Champaign: Children and Family Resource Center, University of Illinois.

Individuals with Disabilities Education Act. (2004). 20 U.S.C. 1400 et seq., revised and amended by P. L. 108-466, Stat. 34. Retrieved from http://www. ed.gov/legislation/FedRegister/finrule/2006-3/ 081406a.pdf

Jones, D. A., Trudinger, P., \& Crawford, M. (2004). Intelligence and achievement of children referred following sexual abuse. Joumal of Pediatrics and Child Health, 40, 455-460. 
Kelley, B. T., Thomberry, T. P., \& Smith, C. A., (1997). In the wake of childhood maltreatment. Washington, DC: Office of Juvenile Justice and Delinquency Prevention, U.S. Department of Justice.

Koenig, A. L., Cicchetti, D., \& Rogosch, F. A. (2000). Child compliance/noncompliance and maternal contributors to internalization in maltreating and nonmaltreating dyads. Child Development, 71, 1018-1032.

Kurtz, P. D., Gaudin, J. M., Wodarski, J. S., \& Howing, P. T. (1993). Maltreatment and the school-aged child: School performance consequences. Child Abuse \& Neglect, 17, 581-589.

Lansford, J., Dodge, K. A., Pettit, G. S., Bates, J. E., Crozier, J., \& Kaplow, J. (2002). A 12-year prospective of the long-term effects of early child physical maltreatment on psychological, behavioral, and academic problems in adolescence. Archives of Pediatric and Adolescent Medicine, 156, 824-830.

Leiter, J. (2007). School performance trajectories after the advent of reported maltreatment. Children and Youth Services Review, 29, 363-382.

Leiter, J., \& Johnsen, M. C. (1994). Child maltreatment and school performance. American Joumal of Education 201, 154-189.

Leiter, J., \& Johnsen, M. C. (1997). Child maltreatment and school performance declines: An event-history analysis. American Educational Research Joumal, 34, 563-589.

Margolin, G., \& Gordis, E. B. (2000). The effects of family and community violence on children. Annual Review of Psychology, 51, 445-479

McGill, D. E., Mihalic, S. F., \& Grotpeter, J. K. (1998). Big Brothers Big Sisters of America: Blueprints for violence prevention, book two. Boulder: University of Colorado Center for the Study and Prevention of Violence, Institute of Behavioral Science.

McGloin, J. M., \& Widom, C. S. (2001). Resilience among abused and neglected children grown up. Development and Psychopathology, 13, 1021-1038.

McGrew, K., Dailey, D., \& Schrank, F. (2007). Woodcock Johnson III nomative update: Score differences, what the user can expect and why (assessment service bulletin number nine).Rolling Meadows, IL: Riverside Publishing.

Mears, D., \& Aron, L. (2003). Addressing the needs of youth with disabilities in the juvenile justice system: The current state of knowledge. Washington, DC: Urban Institute. Retrieved from http://www.urban.org/publications/ 410885. html

National Institute of Child Health and Human Development Early Child Care Research Network. (2003). Social functioning in first grade: Prediction from home, child care and concurrent school experience. Child Development, 74, 1639-1662.

National Youths in Care Network. (2001). Who will teach me to learn: Creating positive experiences for youths in care. Ottawa, Ontario, Canada: National Youth in Care Network.

Novotney, L. C., Mertinko, J. L., Lange, J. L., \& Baker, T. K. (2000). Juvenile mentoring program: A progress review. Washington, DC: Juvenile Justice Bulletin, Office of Juvenile Justice and Delinquency Prevention, U.S. Department of Justice.

Ohio Department of Education. (2009). Ohio report card. Retrieved from http://www.ode.state.oh.us/GD/ Templates $/$ Pages $/$ ODE/ODEPrimary aspx?page $=279$

Patterson, G. R., DeBaryshe, B. D., \& Ramsey, E. (1989). A developmental perspective on antisocial behavior. American Psychologist, 44, 329-335.

Perez, C., \& Widom, C. S. (1994). Childhood victimization and long term intellectual and academic outcomes. Child Abuse \& Neglect, 18, 617-633.
Pianta, R. C., LaParo, K. M., Payne, C., Cox, M. J., \& Bradley, R. (2002). The relation of kindergarten classroom environment to teacher, family, and school characteristics and child outcomes. Elementary School Joumal, 201, 225-238.

Ritter, G., Denny, G., Albin, G., Barnett, J., \& Blankenship, V. (2007). The effectiveness of volunteer tutoring programs: $A$ systematic review. Retrieved from http://givewell.org/files/unitedstates/ campbell_academic\%20achievement_tutoring.PDF

Rowe, E., \& Eckenrode, J. (1999). The timing of academic difficulties among maltreated and nonmaltreated children. Child Abuse \& Neglect, 23, 813-818.

Scarborough, A., \& McCrae, J. (2010). School-age special education outcomes of infants and toddlers investigated for maltreatment. Children and Youth Services Review, 32, 80-88.

Shonk, S. M., \& Cicchetti, D. (2001). Maltreatment, competency deficits, and risk for academic and behavioral maladjustment. Developmental Psychology, 37, 3-17.

Slade, E. P., \& Wissow, L. S. (2007). The influence of childhood maltreatment on adolescents' academic performance. Economics of Education Review, 26, 604-614.

Smithgall, C., Gladden, R. M., Howard, E., Goerge, R., \& Courtney, M. E. (2004). Education experiences of children in out-of-home care. Chicago: Chapin Hall Center for Children.

Staudr, M. (2001). Psychopathology, peer relations, and school functioning of maltreated children: A literature review. Children \& Schools, 23, 85-100.

Tate, S. C. (2000). Impediments to academic achievement for African American males in an urban Midwest foster care system (Unpublished doctoral dissertation). Kansas State University, Manhattan, KS.

Thornberry, T. P., Ireland, T. O., \& Smith, C.A. (2001) The importance of timing: The varying impact of childhood and adolescent maltreatment on multiple problem outcomes. Development and Psychopathology, 13, 957-979.

Tolan, P., Henry, D., Schoeny, M., \& Bass, A. (2007). Mentoring interventions to affect juvenile delinquency and associated problems. Retrieved from http://www. campbellcollaboration.org/library.php

Toth, S. L., \& Cicchetti, D. (1996). The impact of relatedness with mothers on school functioning in maltreated youngsters. Joumal of School Psychology, 3, 247-266.

Tuell, J. (2002). Child maltreatment and juvenile delinquency: Raising the level of awareness. Retrieved from http://www.ncjrs.gov/App/Publications/abstract. aspx?ID=199834

U.S. Department of Education. (2007a). National Center for Education Statistics. Retrieved from http://nces.ed. gov/

U.S. Department of Education. (2007b). Reading recovery. Washington, DC: Institute of Education Sciences, What Works Clearinghouse.

U.S. Department of Health and Human Services. (2003). A coordinated response to child abuse and neglect: The foundation for practice. Retrieved from http://www. childwelfare.gov/pubs/usermanuals/foundation/

U.S. Department of Health and Human Services. (2009a). Child and family services reviews: Promising approaches in child welfare. Retnieved from http://www.acf.hhs.gov/ programs/cb/cwmonitoring/promise/states.htm

U.S. Department of Health and Human Services. (2009b). Child maltreatment 2007. Retrieved from http://www. acf.hhs.gov/programs/cb/pubs/cm07/ 
Veltman, M. W., \& Browne, K. D. (2001). Three decades of child maltreatment research: Implications for the school years. Trauma, Violence, $\mathcal{E}$ Abuse, 2, 215-239.

Wasik, B., \& Slavin, R. (1990). One-to-one tutoring produces early reading success; large gains justify cost. Baltimore: Center for Research on Effective Schooling for Disadvantaged Students.

Wiggins, C., Fenichel, E., \& Mann, T. (2007).

Developmental problems of maltreatment children and early intervention options for maltreated children. Washington, DC: U.S. Department of Health and Human Services, Child Protective Services Project.

Wilson, D. B., Gottfredson, D. C., \& Najaka, S.S. (2001). School-based prevention of problem behaviors: A meta-analysis. Joumal of Quantitative Criminology, 17, 247-272.

Wodarski, J., Kurtz, D., Gaudin, J., \& Howing, P. (1990). Maltreatment and the school-age child: Major academic, socioemotional, and adaptive outcomes. Social Work, 35, 506-513.

Yegidis, B., \& Weinbach, R. (2009). Research methods for social workers. Boston, MA: Allyn \& Bacon.

Zolotor, A., Kotch, J., Dufort, V., Winsor, J., Catellier, C., $\&$ Bou-Saada, I. (1999). School performance in a longitudinal cohort of children at risk of maltreatment. Matemal and Child Health Joumal, 3(1), 19-27.

Post-print standardized by MSL Academic Endeavors, the imprint of the Michael Schwartz Library at Cleveland State University, 2014 